\title{
HENSYNET TIL KOHERENS I DEN DYNAMISKE TINGSRETTEN
}

\author{
SVERRE MAGNUS BERGSLID SALVESEN
}

Universitetslektor, UiT Norges arktiske universitet

Sverre Magnus Bergslid Salvesen (født 1989) har en ph.d. i rettsvitenskap fra UiT Norges arktiske universitet (2021). Avhandlingens tittel er «Kreditorvern». Salvesen har tidligere arbeidet som advokatfullmektig og fast advokat hos Arntzen de Besche, hvor han spesialiserte seg innenfor entrepriserett.

\section{Sammendrag}

Innenfor den dynamiske tingsretten har hensynene til å motvirke kreditorsvik, notoritet, publisitet, legitimasjon og god tro vart fremhevet som sentrale. I nyere tid har også hensynet til koherens vart fremhevet $i$ rettsdogmatiske fremstillinger av den dynamiske tingsretten. Artikkelen undersøker om, og eventuelt hvordan, hensynet til koherens kan få betydning ved tolkning av rettsspørsmål som faller innenfor den dynamiske tingsretten. Artikkelen søker å belyse hvordan hensynet til koherens kan komme til uttrykk $i$ den dynamiske tingsretten ved å undersøke tre konkrete rettslige problemstillinger. Disse problemstilingene er tolkningen av lovfestede rettsvernsregler, den ulovfestede overleveringsregelen og den ulovfestede regelen om selvstendig rettsvernshevd. Gjennom eksemplene søker artikkelen å fremheve både positive og negative sider ved å vektlegge hensynet til koherens innenfor den dynamiske tingsretten.

\section{Nøkkelord}

Koherens, konsistens, hensyn, dynamisk tingsrett, rettighetskollisjoner, ekstinksjon, rettsvern, overlevering 


\section{INNLEDNING ${ }^{1}$}

Innenfor den dynamiske tingsretten er det vanlig å sondre mellom regler som åpner for godtroekstinksjon, og regler som åpner for kreditorekstinksjon. Ulike hensyn fremheves ofte som grunnleggende for disse to regelsettene. For regler om godtroekstinksjon fremheves ofte hensynet til legitimasjon og god tro som sentralt. For regler om kreditorekstinksjon er det først og fremst hensynet til å motvirke kreditorsvik som er sentralt, noe som ofte søkes oppnådd gjennom å oppstille enkelte krav til notoritet og publisitet.

I den senere tid har særlig Hans Fredrik Marthinussen fremhevet hensynet til koherens som et relevant hensyn innenfor den dynamiske tingsretten. Marthinussen skriver blant annet at hensynet til koherens skal sørge for en «indre sammenheng i reglene», og at «[d]et er lite gunstig om det er vilkårlige forskjeller mellom nært beslektede regler». ${ }^{2}$ Gjennom «en helhetlig tilnærming til rettsanvendelsen og reelle hensyn» hevdes det at forutberegneligheten styrkes. ${ }^{3}$

Temaet for denne artikkelen er å undersøke nærmere om, og eventuelt hvordan, hensynet til koherens kan få betydning ved tolkningen av rettsspørsmål innenfor den dynamiske tingsretten. Artikkelen tar utgangspunkt i norsk rett. Likevel vil tankegods om koherens også kunne være av relevans for tilsvarende rettsspørsmål i svensk og dansk rett. I punkt 2 vil jeg redegjøre litt nærmere for min forståelse av koherensbegrepet. Deretter vil jeg i punkt 3 drøfte enkelte særtrekk ved den dynamiske tingsretten som kan tilsi at hensynet til koherens bør vektlegges i rettsanvendelsen. I punkt 4, 5 og 6 vil jeg drøfte tre eksempler på konkrete rettslige spørsmål som har vært behandlet i domstolen og i litteraturen. Hensikten med eksemplene er å vise hvordan hensynet til koherens har kommet direkte eller indirekte til uttrykk. Gjennom disse tre eksemplene ønsker jeg også å fremheve noen uheldige virkninger av å vektlegge hensynet til koherens for mye. Avsluttende betraktninger fremsettes i punkt 7.

\section{HVA ER KOHERENS?}

I en rettsvitenskapelig kontekst kan begrepet koherens kanskje hevdes å operere på flere ulike plan. I kontekst av juridisk metode eller rettsfilosofi finnes det eksempler på at koherens fremheves som et generelt vitenskapsideal for rettsvitenskapen, og kanskje særlig innenfor

\footnotetext{
${ }^{1}$ Artikkelen er basert på min prøveforelesning over oppgitt emne til den juridiske doktorgraden 12. februar 2021. En stor takk rettes til Bjørn Løtveit som har lest gjennom artikkelen og kommet med nyttige innspill.

${ }^{2}$ Hans Fredrik Marthinussen: Tredjemannsproblemene, 2. utgave, Oslo 2019 s. 105.

${ }^{3}$ Marthinussen: Tredjemannsproblemene s. 239.
} 
rettsdogmatisk metode. ${ }^{4}$ Innenfor rettsdogmatisk metode inntar forskeren et internt perspektiv på retten. Forskeren underkaster seg de spillereglene som rettssystemet hviler på, og står for eksempel ikke fri til å velge bort enkelte rettskilder eller prinsipper som irrelevante dersom de kan bidra til å løse et rettslig spørsmål. Ei heller kan forskeren unndra seg fra de vurderingskriteriene som rettsdogmatikken oppstiller for holdbar argumentasjon. ${ }^{5}$ Som et generelt rettsvitenskapelig ideal kan kanskje koherens innebære at forskeren fremstiller retten og rettslige argumenter på en måte som fremmer et helhetlig, strigent, konsistent og logisk system. ${ }^{6}$ For å oppnå koherens bør rettsanvenderen vurderer om et tolkningsresultat harmonerer med grunnleggende prinsipper og verdier som ligger til grunn for rettssystemet, for deretter å balansere disse - av og til motstridende - verdiene mot hverandre på en så bevisst og grundig måte som mulig. ${ }^{7}$ På denne måten skal rettsanvenderen sørge for at argumentasjonen ivaretar den indre «helheten» $\mathrm{i}$ jussen. ${ }^{8}$ Rettsanvenderen frikobler seg dermed fra egne oppfatninger og vurderinger av hva som er rett og galt, og tar heller utgangspunkt i presumtivt mer omforente rettningslinjer for tolkningen. ${ }^{9}$ Gjennom å systematisere rettsstoffet på en måte som ivaretar disse idealene, bidrar rettsdogmatikken til å fremme koherens.

Koherens har berøringsflater til andre rettsdogmatiske idealer. Et generelt krav til rettsdogmatisk argumentasjon er at rettsanvendelsen er konsistent. Med konsistent rettsanvendelse forstår jeg i denne sammenhengen at like faktiske tilfeller bedømmes rettslig likt. Dette kan kanskje omtales som en snever forståelse av konsistens. ${ }^{10} \mathrm{I}$ andre sammenhenger kan konsistens ha en annen og videre betydning, for eksempel ved at rettsanvenderen må være

\footnotetext{
${ }^{4}$ Knut Martin Tande: «Individuelle valg og vurderinger i rettsanvendelsesprosessen», Jussens Venner nr. 1/2011 (Volum 46) s. 1-36 på s. 13-14. DOI: https://doi.org/10.18261/ISSN1504-3126-2011-01-01 og Bjarte Askeland: «Om rettsdogmatisk metode og sammenligning» i Søvig m.fl. (red.): Undring og erkjennelse. Festskrift til Jan Fridthjof Bernt 70 år, Bergen 2013 s. $15-25$ på s. 20-21.

${ }^{5}$ Bjarte Thorson: Erstatningsrettslig vern for rene formuestap, Oslo 2011 s. 20.

${ }^{6}$ Aleksander Peczenik: «Om rättens förnuftiga vidareutveckling - ett bemötande», Tidsskrift for Rettsvitenskap nr. 5/1986 (Volum 148) s. 677-693 på s. 681. DOI: https://doi.org/10.18261/ISSN1504-3096-1986-05-04, Anne Marie Frøseth: «Materiell koherens i formueretten generelt, og erstatningsretten spesielt», i Søvig m.fl. (red.): Undring og erkjennelse. Festskrift til Jan Fridthjof Bernt 70 år, Bergen 2013, s. 141-151 på s. 143, Jan Fridthjof Bernt: «Den dynamiske dimensjon i rettskildelæren» i Kai Krüger m.fl. (red.): Nybrott og Odling - Festskrift til Nils Nygaard på 70-årsdagen 3. april 2002, Bergen 2002 s. 259-272 på s. 271 og Jonatan Schytzer: Fordrans uppkomst inom insolvensrätten, Uppsala 2020 s. 164-165.

${ }^{7}$ Thorson: Erstatningsrettslig vern for rene formuestap s. $20 \mathrm{og}$ Tande: «Individuelle valg og vurderinger» s. 13.

${ }^{8}$ Tande: «Individuelle valg og vurderinger» s. 13-14 og Marthinussen: Tredjemannsproblemene s. 239.

${ }^{9}$ Marthinussen: Tredjemannsproblemene s. 239-241.

${ }^{10}$ Se Ronald Dworkin: Law's Empire, Cambridge 1986 s. 219-224.
} 
konsistent i sin kildebruk eller ved at lovgiver og rettsanvender må være konsistent i hvilke formål som søkes ivaretatt gjennom lover og avgjørelser. ${ }^{11}$

Det er en klar sammenheng mellom konsistent rettsanvendelse og koherens. Innholdet i konsistens og koherens kan også tenkes å være mer eller mindre overlappende på bakgrunn av hvilken forståelse som legges til grunn for konsistens og koherens, uten at jeg skal gå nærmere inn på dette her. Koherens kan imidlertid sies å stille krav til noe mer enn bare konsistent rettsanvendelse i snever forstand, ettersom koherens forutsetter at resultatet ikke bare ses i lys av tidligere rettslige avgjørelser, men at løsningen også ses i lys av rettssystemet som helhet. Koherens skal sørge for at rettslige argumenter eller rettslige avgjørelser passer, underbygger og er i tråd med de rettslige kildene, prinsippene og verdiene som rettsystemet utpeker som relevante. ${ }^{12}$ For å bruke Bjarte Askelands ord kan det hevdes at «konsistente løsninger av ulike rettsspørsmål innenfor et avgrenset rettsområde er nødvendig, men ikke tilstrekkelig for å oppnå koherens». ${ }^{13}$ Selv om Askeland fremhever konsistente løsninger som nødvendig for å oppnå koherens, må ikke dette forstås slik at like tilfeller alltid må bedømmes likt. Rettskildene kan være gjenstand for endring over tid. Endringer i rettskildebildet kan tale for at den rettslige løsningen som tidligere ble lagt til grunn, fravikes i en etterfølgende sak. Hensynet til koherens kan i slike tilfeller tale for at en rettslig løsning som tidligere ble antatt å være riktig, fravikes, se for eksempel punkt 5.

Koherens trenger ikke alltid å komme eksplisitt til utrykk i rettsdogmatiske fremstillinger. Rettsdogmatiske fremstillinger bygges vanligvis ikke opp etter tilfeldigheter. Ordvendinger som «sammenheng», «system» og «konsekvens» kan brukes for å underbygge et fremstillingsgrep eller et tolkningsresultat. ${ }^{14}$ I slike tilfeller kan koherenstankegods ligge til grunn for de valgene som er tatt, uten at koherens eksplisitt fremheves som en begrunnelse. ${ }^{15}$ Kåre Lilleholt har vært inne på tankegods som klart er i berøring med koherens, uten at han selv

\footnotetext{
${ }^{11}$ Se for eksempel Gjermund Mathisen: «Consistency and coherence as conditions for justification of member state measures restricting free movement», Common Market Law Review nr. 4/2010 (volum 47) s. 1021-1048 hvor Mathisen undersøker ECJs bruk av konsistens som vilkår for at stater kan fatte tiltak som kan begrense fri flyt. På s. 1023 beskrives konsistens som «the fact that nothing is allowed to counteract the attainment of a public interest objective (purportedly) pursued by a given measure, for example national legislation. More generally, consistency thus basically equals an absence of contradictions in pursuit of such an objective.» (kursivering i original).

${ }^{12}$ Se til sammenligning Mathisen: «Consistency and coherence as conditions for justification of member state measures restricting free movement» s. 1024.

${ }^{13}$ Se Bjarte Askeland: Erstatningsrettslig identifikasjon, Oslo 2002 s. 38 (petit) med videre henvisninger.

${ }^{14}$ Se for eksempel Kåre Lilleholt: Allmenn fomurett. Fleire rettar til same formuesgode, 2. utgave, Oslo $2018 \mathrm{~s}$. 24 («konsekvens og samanheng»), Peter Mortensen: Indledning til tingsretten - tredjemanskonflikter vedrørende løsøre, 2. utgave 2012 s. 248 («systemfremmed»), Jonatan Schytzer: Fordrans uppkomst inom insolvensrätten s. 166 («systemargument»), Borgar Høgetveit Berg: Beslagsretten, Oslo 2021 s. 415 («Systemet har ein indre samanheng som må vera konsistent») og Rt. 1996 s. 1647 på s. 1654 («mindre god indre sammenheng»).

${ }^{15}$ Askeland: «Om rettsdogmatisk metode og sammenligning» S. 21.
} 
bruker dette begrepet. Om bruk av reelle hensyn som rettskildefaktor skriver Lilleholt blant annet følgende:

«Langt på veg kan vi seie at bruk av reelle omsyn er å stille spørsmålet rett. Som kjent er ein ofte minst halvvegs til svaret når ein har stilt spørsmålet rett. Å stille spørsmålet rett er eit ledd i det vi kan kalle ein analyse av det problemet vi står overfor. For å gjera dette må vi først og fremst vita kva føremål dei aktuelle reglane har, kva problemstillingar og interessemotsetningar som gjer seg gjeldande på vedkomande rettsområde, og kva verknadene blir av den eine eller den andre løysinga. Ofte samanfattar vi dette som eit spørsmål om reelle omsyn, men vi ser at det ikkje er noka påhengt vurdering, men i mange tilfelle sjølve 'konstitueringa' av drøftinga.»1 16

Selv om Lilleholt i det nevnte sitatet ikke nevner koherens spesifikt, synes jeg tankegodset som presenteres er dekkende for hvordan koherens kan komme til uttrykk som rettsvitenskapelig ideal: Det handler om å stille spørsmålet riktig på det rettsområdet man befinner seg på, være bevisst på hvorfor spørsmålet må stilles på den aktuelle måten og identifisere de riktige redskapene for å besvare spørsmålet.

I et forsøk på å billedgjøre koherens som rettsvitenskapelig ideal, kan vi se for oss rettsvitenskapen som et stort puslespill. Hver enkelt brikke i puslespillet vil, i denne analogien, utgjøre enkeltfragmenter av rettsvitenskapen. En enkelt brikke kan for eksempel være et rettslig prinsipp, hensyn eller til og med noe så lite som en enkelt lovbestemmelse. Alene vil puslebrikkene ha liten verdi. Det er først når vi legger puslebrikkene sammen på de plassene de hører hjemme, at brikkene samlet utgjør et helhetlig bilde. Koherens kan kanskje sies å være retningslinjen som sørger for at vi legger puslebrikkene på de plassene de hører hjemme, og ikke på plasser som får det endelige bildet til å fremstå som skjevt eller ufullstendig.

Koherens trenger ikke bare å ha funksjon som et rettsvitenskapelig ideal. For å bruke Kaarlo Tuoris bilde av retten som et lagdelt system, kan det hevdes at hensynet til koherens ikke bare er relevant på rettens mellomnivå og dypstruktur, men at hensynet til koherens også kan tenkes å være relevant på rettens overflatenivå. ${ }^{17}$ Det kan derfor kanskje sondres mellom koherens som

\footnotetext{
${ }^{16}$ Kåre Lilleholt: «Bruk av reelle omsyn i formueretten», Jussens Venner 2000 s. $49-60$ på s. 50 . DOI: https://doi.org/10.18261/ISSN1504-3126-2000-02-01.

${ }^{17}$ Om Tuoris bilde av retten som et lagdelt system, se for eksempel Kaarlo Tuori: Critical Legal Positivism, New York 2002 s. 147 flg. DOI: https://doi.org/10.4324/9781315258867.
} 
et allment rettsvitenskapelig ideal på den ene siden, og koherens som et lokalt eller områdespesifikt hensyn på den andre siden. ${ }^{18}$

Koherens vil ha mye av det samme siktemålet når det fungerer som områdespesifikt hensyn og rettsvitenskapelig ideal. For å gå tilbake til puslespillanalogien skal koherens som områdespesifikt hensyn sørge for at brikkene legges på rett plass slik at det endelige puslespillet fremstår som et helhetlig bilde. Forskjellen er først og fremst at puslespillet som skal legges når vi bruker koherens som et områdespesifikt hensyn, er mye mindre enn når koherens fungerer som rettsvitenskapelig ideal. Når koherens opptrer som et områdespesifikt hensyn, kan det derfor være andre og mer spesifikke prinsipper og verdier som ligger til grunn for systemet som er gjenstand for undersøkelse, enn dersom rettsystemet som helhet utgjør objektet for undersøkelser. ${ }^{19}$ Når jeg omtaler hensynet til koherens i den følgende artikkelen, sikter jeg til koherens som et områdespesifikt hensyn innenfor den dynamiske tingsretten, og ikke koherens som et allment rettsvitenskapelig ideal.

Etter mitt skjønn kan koherens som områdespesifikt hensyn opptre på minst to ulike måter. Den første måten er at koherens brukes som et hensyn i den konkerete rettsanvendelsen. Når koherens brukes på denne måten, kan det fungere som et støtteargument som taler for et konkret tolkningsresultat. Koherens kan da sies å fungere som et «metahensyn»: Et resultat kan aldri forankres i hensynet til koherens alene, men koherens kan være med å underbygge at øvrige kilder som rettsanvenderen har bygget sitt resultat på, er relevante og må tillegges vekt.

Den andre måten koherens kan brukes på, er at koherens brukes som en beskrivelse av et konkret tolkningsresultat. Et tolkningsresultat kan vurderes i lys av verdiene, prinsippene, hensynene og strukturen til det rettssystemet som tolkningen relaterer seg til. Dersom tolkningsresulatet er egnet til å fremme verdiene bak rettssystemet, vil det være koherent, og vice versa. Dette må ikke forstås slik at rettslig argumentasjon enten er koherent eller ikke. Slik jeg ser det kan det eksistere grader av koherent argumentasjon: Et argument kan i større eller mindre grad være egnet til å fremme de verdiene, prinsippene, hensynene og strukturen som ligger til grunn for et rettsområde.

\footnotetext{
${ }^{18}$ I denne retning, se Kaarlo Tuori: «Om rättssäkkerhet och sociala rättigheter (samt mycket anna)», Tidsskrift for Rettsvitenskap nr. 3/2003 (Volum 116) s. 341-365 på s. 364. DOI: https://doi.org/10.18261/ISSN1504-3096-200303-01. Se også Schytzer: Fordrans uppkomst inom insolvensrätten s. 178.

${ }^{19}$ Se Frøseth: «Materiell koherens i formueretten generelt, og erstatningsretten spesielt» s. 144 hvor det fremgår at et rettsvitenskapelig krav om koherens «betyr ikke at det ikke kan eksistere susbsystemer eller mer autonome elementer $i$ et system av regler».
} 


\section{I HVILKEN GRAD BØR HENSYNET TIL KOHERENS}

\section{VEKTLEGGES I DEN DYNAMISKE TINGSRETTEN?}

Med «den dynamiske tingsretten» siktes det ofte til rettsforhold der to eller flere rettssubjekter har rettigheter i det samme formuesgodet, og hvor rettighetene ikke fullt ut er fornelige etter sitt innhold. ${ }^{20} \mathrm{Vi}$ kan gjerne si at den dynamiske tingsretten tar for seg hvordan formuesgoder oppfører seg i «overføringsfasen». ${ }^{21}$ Fokus for den dynamiske tingsretten er hvilken rettsvirkning en overføringen av et formuesgode har for tredjeperson. ${ }^{22}$ Tredjeperson kan i den dynamiske tingsretten være flere ulike aktører, men det er vanlig å sondre mellom tilfeller der tredjeperson er kreditor og der tredjeperson er godtroerverver. ${ }^{23}$ Det rettslige spørsmålet som ofte stilles er hvorvidt tredjeperson kan ekstingvere en konkurrerende rettighet i det overførte formuesgodet, eller om en eldre stiftet rettighet skal stå seg på bekostning av tredjepersons rett.

Koherens har ikke i særlig grad vært eksplisitt fremhevet som et grunnleggende hensyn innenfor den dynamiske tingsretten. ${ }^{24}$ Som nevnt i punkt 1 fremheves ofte hensynene til legitimasjon og god tro som sentrale for regler om godtroekstinksjon, mens hensynet til å motvirke kreditorsvik gjennom å oppstille krav til notoritet og publisitet er sentralt for regler om kreditorekstinksjon. ${ }^{25}$

Selv om hensynet til koherens i liten grad fremheves eksplisitt innenfor den dynamiske tingsretten, er det en rekke særtrekk ved den dynamiske tingsretten som taler for at hensynet til koherens bør gis et økt fokus. Rettsvernsreglene i de skandinaviske landene hevdes å bygge på en funksjonell tilnærming til eiendomsretten. ${ }^{26}$ Etter den funksjonelle tilnærmingen til

\footnotetext{
${ }^{20}$ Lilleholt: Allmenn fomurett s. 17.

${ }^{21}$ Lilleholt: Allmenn formuerett s. 18.

22 Thor Falkanger og Aage Thor Falkanger: Tingsrett, 8. utgave, Oslo 2016 s. 579-580.

${ }^{23}$ Tilsvarende sondring foretas også i svensk og dansk rett, se Johan Sandstedt: «Godtrosförvärvsreglerna, stöldfallet, försäkringsbolags vindikationsrätt och borgenärskydd - och äganderätten» i Gorton m.fl.: Festskrift till Göran Millqvist, Stockholm 2019 s. 525-555 på s. 529 med videre henvisninger og Mortensen: Indledning til tingsretten s. 85 .

${ }^{24}$ Hans Fredrik Marthinussen utgjør et unntak i denne sammenhengen, se Marthinussen: Tredjemannsproblemene kapittel 12 og Hans Fredrik Marthinussen: «'Forusstranda': Kreditorvern ved fisjon og fusjon, rettsvernshevd og formuerettslige metodespørsmål», Jussens Venner nr. 2/2017 (Volum 52) s. 67-97 på s. 73-74 og s. 85. DOI: https://doi.org/10.18261/issn.1504-3126-2017-02-01.

${ }^{25}$ For en oversikt over hensynene bak ekstinksjonsreglene, se blant annet Sjur Brækhus: Omsetning og kreditt 3 og 4. Omsetningskollisjoner I og II, Oslo 1998 s. 28-48, Lilleholt: «Legitimasjon, publisitet og notoritet» s. 69-97 og Høgetveit Berg: Beslagsretten s. 228-231.

${ }^{26}$ Brækhus: Omsetning og kreditt 3 og 4 s. 3, Marthinussen: Tredjemannsproblemene s. 25, Hilde Hauge: Løsøreerververs kreditorvern, Bergen 2016 s. 58, Stig Solheim: «Eiendomsrettsbegrepet - refleksjoner fra fagseminar i Tromsø», Tidsskrift for eiendomsrett nr. 2/2006 (volum 2) s. 105-108 på s. 106-107. DOI: https://doi.org/10.18261/ISSN0809-9529-2006-02-02, Høgetveit Berg: Beslagsretten s. 26-27, Göran Millqvist: Sakrättens grunder. En lärobok $i$ sakrättens grundläggande frågeställningar avseende lös egendom, 8. utgave, Stockholm 2018 s. 26, Claes Martinson: «Ejendomsrettens overgang - Norden kontra verden», Forhandlingene
} 
eiendomsretten anses ikke eiendomsretten som en enhet som må opptre samlet. I stedet anses eiendomsretten som et koblingsord mellom stiftelsesgrunnlaget og de ulike rettsvirkningene som utløses gjennom ervervet (rett til å selge, leie bort, pantsette, bruke m.m.). ${ }^{27}$ Den funksjonelle tilnærmingen til eiendomsretten legger opp til at de hensynene som gjør seg gjeldende $\mathrm{i}$ et konkret typetilfelle, kan vurderes og avveies. Lovgiver søker dermed, gjerne i samspill med rettsanvender, å oppnå gode resultater i de typetilfellene som kan tenkes å oppstå. ${ }^{28}$ En naturlig følge av den funksjonelle tilnærmingen til eiendomsretten er blant annet at den dynamiske tingsretten er et fragmentert rettsområde. ${ }^{29}$ Det er mange ulike lover som inneholder regler om godtroekstinksjon og kreditorekstinksjon for ulike typer formuesgoder. For å unngå at rettsanvendelsen blir lite forutberegnelig, er det behov for at regler som har en nær rettslig sammenheng, tolkes på en forutsigbar måte. Sagt på en annen måte: Det er behov for at regler som behandler henholdsvis godtroekstinksjon og kreditorekstinksjon, tolkes koherent.

Hensynet til koherens vil ikke bare være relevant ved tolkningen av lovfestede regler innenfor den dynamiske tingsretten. Koherens kan også tenkes å komme inn som et reelt hensyn ved ulovfestet rettsdannelse på den dynamiske tingsrettens område. Når de lovfestede reglene er utformet og tolket på en klar og entydig måte, vil det være uheldig om ulovfestede regler bygger

ved det 38. nordiske Juristmøde i København 2008, publisert i Kavita Bäck Mirchandani og Kristina Ståhl (red.): Förhandlingarna vid Det 39:e nordiska juristmötet i Stockholm 18-19 augusti 2011. Del II, Stockholm 2012 s. 823-843 på s. 824, Schytzer: Fordrans uppkomst inom insolvensrätten s. 175, Joel Samuelsson: «Om harmoniseringen av den europeiska privaträtten och funktionalismens funktionalitet», Europarättslig tidskrift nr. 1/2009 (volum 12) s. 63-86 på s. 64-66 og Johan Sandstedt: Sakrätten, Norden och europeiseringen. Nordisk funktionalism möter kontinental substansialism, Stockholm 2013 s. 20. Peter Mortensen bruker termen «relationsteorien» istedenfor teorien om den funksjonelle tilnærmingen til eiendomsretten, se Indledning til tingsretten s. 81. Det synes ikke å være noen innholdsmessig forskjell på relationsteorien og teorien om den funksjonelle tilnærmingen til eiendomsretten.

${ }^{27}$ Falkanger/Falkanger: Tingsrett s. 40, Erlend Baldersheim: Til tingsrettens teori, Oslo 2017 s. 18-19, Høgetveit Berg: Beslagsretten s. 26-27 og Eckhoff: Rettskildelcere s. 49-51. Svensk og dansk rett har en lignende tilnærming til eiendomsbegrepet, se Millqvist: Sakrättens grunder s. 24-25 og Mortensen: Indledning til tingsretten s. 81.

${ }^{28}$ For en gjennomgang av eksempler på hvordan den funksjonelle tilnærmingen fungerer i praksis, se Claes Martinsson: «How Swedish Lawyers Think about 'Ownership' and 'Transfer of Ownership' - Are We Just Peculiar or Actually Ahead?» i Wolfgang Faber og Birgitta Lurger (red.): Rules for the Transfer of Movables. A Candidate for European Harmonisation or National Reforms?, München 2008 s. 69-95 på s. 72-92. Se også Wolfgang Faber: «Sceptisism about the Functional Approach from a Unitary Perspective» i Wolfgang Faber og Birgitta Lurger (red.): Rules for the Transfer of Movables. A Candidate for European Harmonisation or National Reforms?, München 2008 s. 97-122 på s. 97-99. Joel Samuelsson har problematisert om de «neutrala 'bästa lösningar'» eksisterer som objektive fenomener, eller om ulike rettslige løsninger bare er et uttrykk for ulike rettskulturer, se Samuelsson: «Om harmoniseringen av den europeiska privaträtten och funktionalismens funktionalitet»s. 65 og s. 84 .

${ }^{29}$ Dette fremheves også i svensk rett, se Sandstedt: «Godtrosförvärvsreglerna, stöldfallet, försäkringsbolags vindikationsrätt och borgenärskydd - och äganderätten» s. 532. Se også Christian von Bar og Eric Clive (red.): Principles, Definitions and Model Rules of European Private Law. Draft Common Frame of Reference (DCFR). Full Edition, volum 5, München 2009 s. 4438 hvor følgende står om svensk, dansk, norsk og finsk rett: «The property law rules in these legal systems are based on fragmented legislation and court practice.» 
på helt andre prinsipper og hensyn enn de lovfestede rettsvernsreglene. Hensynet til koherens kan derfor tale for at prinsippene og hensynene som ligger til grunn for de lovfestede ekstinksjonsreglene, danner en ytre ramme for hvilke hensyn som er relevante å se hen til i den ulovfestede regeldanningsprosessen.

Det er også øvrige grunner til at behovet for koherens er stort innenfor den dynamiske tingsretten. Erververe og kreditorer har et behov for å kunne forutse sin rettslige stilling. Dersom ekstinksjonsreglene er uklare, kan kredittaktører potensielt begynne å regne inn en høyere risiko i sine lånevilkår. Uklare ekstinksjonsregler kan også gjøre markedsplassen utrygg for potensielle kjøpere. I verste fall vil en mangel på system innenfor den dynamiske tingsretten føre til at markedsaktører foretrekker å gjemme pengene sine vekk i den trygge madrassen fremfor å investere pengene.

Hensynet til koherens kan imidlertid også føre med seg noen uheldige sider dersom det vies for stor plass innenfor den dynamiske tingsretten. For det første kan et for stort fokus på koherens bidra til å sperre for rettsutvikling. Dersom det blir et mål i seg selv at samtlige tolkningsresultater er systemtro, kan systemet bli så rigid at adgangen til rettsutvikling minskes. ${ }^{30}$ Prinsippene og verdiene som ligger til grunn for tingsretten kan bli så enerådende at nye verdier, prinsipper og hensyn som kan vokse til når markedsplassen utvikler seg, ikke blir inkorporert i rettssystemet, jf. punkt 5. Dette kan kanskje motvirkes gjennom at systemet som ligger til grunn for den dynamiske tingsretten åpner for en viss fleksibilitet og dermed evner å tilpasse seg endrede verdier og behov. ${ }^{31}$

Videre kan hensynet til koherens i enkelte tilfeller være tvetydig. Med tvetydig mener jeg i denne sammenhengen at hensynet til koherens kan utpeke flere aktuelle tolkningsalternativer som «riktige» og «systemtro», jf. punkt 4. Ulike forståelser og oppfatninger av systemet som ligger til grunn for den dynamiske tingsretten, kan føre til ulike koherensslutninger, jf. punkt 6 .

Til slutt kan en mulig uheldig side ved koherenshensynet være at en for slavisk anvendelse av hensynet til koherens åpner for systemslutninger som ikke har støtte i rettskildene for øvrig. Som eksempel kan det vises til at den dynamiske tingsretten ofte fremstilles gjennom bruk av konfliktillustrasjonene H-A-B og A-S-B, også kjent som hjemmelmannskonflikten og

\footnotetext{
${ }^{30}$ Tørum synes å mene at farene for at rettsutviklingen hemmes gjennom et for stort fokus på koherens, er svært små i norsk rett, se Amund Bjøranger Tørum: «Konsekvens i formueretten», Jussen Venner nr. 4-5/2002 s. 314339 på s. 333 (fotnote 70). DOI: https://doi.org/10.18261/ISSN1504-3126-2002-04-05-10.

${ }^{31}$ I denne retning, se Thorson: Erstatningsrettslig vern for rene formuestap s. 20.
} 
suksesjonskonflikten. ${ }^{32}$ Disse konfliktillustrasjonene er ment å være pedagogiske hjelpemidler som skal forklare systemet bak ekstinksjonsreglene $i$ loven. 33 Begrepene hjemmelsmannskonflikt og suksesjonskonflikt er ikke mulig å gjenfinne noen steder i loven. Selv om konfliktmodellene ikke er å gjenfinne i loven, blir enkelte ekstinksjonsbestemmelser tolket i lys av konfliktmodellene i stedet for at ordlyden i bestemmelsene settes i fokus. ${ }^{34}$ Litt av kritikken som i sin tid ble rettet mot den substansielle tilnærmingen til eiendomsretten var nettopp at den åpnet for begrepsslutninger. Hensynet til koherens bør derfor ikke strekkes så langt at det åpner for at det trekkes rettslige slutninger fra for eksempel hjelpemodellene H-AB og A-S-B. ${ }^{35}$

Jeg har nå fremhevet noen fordeler og ulemper ved å vektlegge hensynet til koherens i den dynamiske tingsretten. I det følgende vil jeg gå nærmere inn på tre eksempler fra rettspraksis og teori som skal illustrere hvordan hensynet til koherens har kommet til uttrykk i drøftelser av rettsspørsmål som relaterer seg til den dynamiske tingsretten.

\section{TOLKNINGEN AV LOVFESTEDE RETTSVERNSREGLER}

Ved tolkningen av lovfestede rettsvernsregler er det viktig å vurdere den enkelte regelen i lys av systemet som regelen inngår i. Det kan imidlertid være tilfeller hvor flere tolkningsresultater kan hevdes å være systemtro. I slike tilfeller vil det være uklart om og eventuelt hvilken vekt hensynet til koherens bør tillegges. HR-2017-33-A (Forusstranda-dommen) kan fungere som eksempel. I Forusstranda-dommen måtte Høyesterett ta stilling til om fem eiendommer som var blitt overdratt til nystiftede selskaper i forbindelse med en selskapsrettslig fisjon, kunne beslaglegges av grunnbokshjemmelshaverens kreditorer. Tinglysingsloven $\S 23$ krever at rettigheter i fast eiendom som er «stiftet ved avtale», tinglyses senest dagen før konkursåpningen for å stå seg overfor et konkursbeslag. ${ }^{36}$ Begrepet «avtale» synes å sikte til en enighet mellom to parter, og det var derfor ikke klart om ensidige beslutninger, som for eksempel en fisjonsoverføring til et nystiftet selskap, også var rammet av formuleringen «stiftet ved avtale» i tinglysingsloven $\S 23$.

\footnotetext{
${ }^{32}$ Se blant annet Lilleholt: Allmenn formuerett s. 29 og Falkanger og Falkanger: Tingsrett s. 581.

${ }^{33}$ Falkanger/Falkanger: Tingsrett s. 581 og Høgetveit Berg: Beslagsretten s. 31.

${ }^{34}$ Se for eksempel Falkanger/Falkanger: Tingsrett s. 675: «For fast eiendom er tgl. $\S 27$ av sentral betydning for hjemmelskonfliktene.» Se også Falkanger/Falkanger: Tingsrett s. 724: «Reglene om at dagbokføringstidspunktet er avgjørende hvor det er konflikt mellom B og S, finnes i tgl. § 20 første ledd [...]».

${ }^{35}$ I samme retning, se Aage Thor Falkanger: «Sjur Brækhus: Omsetning og kreditt 3 og 4 Omsetningskollisjoner I og II» (bokanmeldelse), Lov og Rett nr. 1/2000 (Volum 39) s. 56-64 på s. 59. DOI: https://doi.org/10.18261/issn1504-3061-2000-01-05 og Høgetveit Berg: Beslagsretten s. 31.

${ }^{36}$ Lov 7. juni 1935 nr. 2 om tinglysing.
} 
I tolkningen av tinglysingsloven $\S 23$ la Høyesterett vekt på hvordan reglene i sjøloven $\S 25$, borettslagsloven $\S 6-11$ og luftfartsloven $\S 3-31$ var formulert. ${ }^{37}$ Etter disse bestemmelsene må enhver «frivillig stiftet rett» være innført i dagboken senest dagen før konkursåpning for å stå seg mot et konkursbo. Dette mente Høyesterett ga vesentlige holdepunkter for at begrepet «avtale» i tinglysingsloven $\S 23$ måtte forstås som «frivillig stiftet rett». ${ }^{38}$ Høyesterett konluderte med at en eiendomsoverdragelse i forbindelse med en utfisjonering falt innenfor begrepet «rett som er stiftet ved avtale» i tinglysingsloven $\S 23 .{ }^{39}$

Det at Høyesterett tolket tinglysingsloven $\S 23$ i lys av sjøloven $\S 25$, borettslagsloven $\S 6-11$ og luftfartsloven $\S 3-31$, kan kanskje ses på som et utslag av hensynet til koherens. Alle de nevnte reglene har en nær rettslig sammenheng, ettersom samtlige av bestemmelsene regulerer hvordan suksessor kan etablere rettsvern overfor et konkursbo gjennom rettsregistrering. Bestemmelsene kan samlet sies å gi uttrykk for en felles tanke om hvordan kreditorvern etableres overfor konkursbo når rettsregistrering er rettsvernsakten. Hensynet til koherens kan derfor tale for at tinglysingsloven $\S 23$ tolkes utvidende slik at den er i harmoni med de øvrige lovfestede reglene om rettsregistrering. Hensynet til koherens kunne imidlertid også hypotetisk sett talt for at sjøloven $\S 25$, borettslagsloven $\S 6-11$ og luftfartsloven $\S 3-31$ skulle tolkes innskrenkende, slik at disse bestemmelsene ble tolket likt som tinglysingsloven $\S 23 .{ }^{40}$ Tinglysingsloven har vært mønsterdannende for de øvrige reglene om rettsregistrering, og tinglysingsloven $\S 23$ kan derfor hevdes å være forbildet til de etterfølgende rettsvernsbestemmelsene i sjøloven, borettslagsloven og luftfartsloven. Etter mitt skjønn bidro derfor ikke hensynet til koherens med særlig avklaring ved tolkningen av tinglysingsloven $\S 23$ i Forusstranda-dommen.

Hensynet til koherens kunne også åpnet for alternative tolkningsresultater i Forusstrandadommen. Avtale er et etablert rettslig begrep med et forholdsvis klart innhold. Etter mitt skjønn kan det vanskelig sies at en selskapsrettslig fisjon naturlig kan falle innenfor begrepet «avtale», særlig dersom avtalebegrepet tolkes i lys av systemet som ligger til grunn for avtaleloven (tilbud og aksept-modellen). I den grad tinglysingsloven $§ 23$ sitt avtalebegrep skulle blitt harmonisert

\footnotetext{
${ }^{37}$ Lov 24. juni 1994 nr. 39 om sjøfarten, lov 6. juni 2003 nr. 39 om burettslag og lov 11. juni 1993 nr. 101 om luftfart.

${ }^{38}$ HR-2017-33-A, avsnitt 37-39.

${ }^{39}$ HR-2017-33-A, avsnitt 44.

${ }^{40}$ Se Hans Fredrik Marthinussen: Tredjemannsproblemene, 1. utgave, Oslo 2016 s. 181-182 hvor Marthinussen synes å mene at hensynet til koherens taler for at «frivillig stiftet rett» i sjøloven $\S 25$ bør tolkes i lys av tinglysingsloven $\S 23$, og at sjøloven $\S 25$ derfor bør tolkes «noe innskrenkende». For ordens skyld nevnes at endelig avgjørelse i Forusstranda-dommen ikke hadde falt da Marthinussen foretok denne drøftelsen. Drøftelsen har blitt justert i den senere utgaven av Tredjemannsproblemene.
} 
med systemet i avtaleloven, ville hensynet til koherens, etter mitt skjønn, talt for at en fisjonsoverføring $i k k e$ var å anse som en avtale.

Videre har Høyesterett en rekke ganger i forkant av Forusstranda-dommen betonet at kreditorvernreglene må være «absolutte» og «firkantede». Dette har blant annet kommet til uttrykk i Rt. 1997 s. 1050 (Momentum-dommen) og Rt. 1998 s. 268 (Dorian Grey-dommen). Når Høyesterett tidligere har vært tilbakeholden med å tolke rettsvernsregler innskrenkende, kunne et potensielt koherenshensyn talt for en tilsvarende tilbakeholdenhet med å tolke kreditorvernregler utvidende, slik Høyesterett gjorde i Forusstranda-dommen. ${ }^{41}$ Kjøpere har et behov for å kunne innrette seg etter det faktum at ervervet er beskyttet mot tredjemenn. At dette koherensbruddet ikke drøftes i Forusstranda-dommen, er lite tilfredsstillende. ${ }^{42}$

Jeg forsøker ikke med dette å si at resultatet i Forusstranda-dommen nødvendigvis var feil. Det var klart nok argumenter som talte i favør å tolke tinglysingsloven $\S 23$ utvidende slik at bestemmelsen også omfattet fisjonsoverføringer, deriblant hensynet til å motvirke kreditorsvik. Poenget jeg ønsker å fremheve i denne sammenheng er at hensynet til koherens ikke nødvendigvis utpekte et klart tolkningsresultat som «det riktige». Hvilken tolkning som best fremmer hensynet til koherens, avhenger av hvilket system, verdipremiss og hensyn som rettsanvenderen legger til grunn for lovtolkningen. Dersom hensynet til koherens kan brukes som et argument for flere ulike tolkningsresultater, bidrar det med lite $\mathrm{i}$ den konkrete rettsanvendelsen. Hensynet til koherens kan i uheldige tilfeller fremheves som begrunnelsen for et tolkningsresultat, mens det i realiteten ikke er klart hvilket tolkningsresultat som best fremmer hensynet til koherens. Etter mitt skjønn bør rettsanvendere være forsiktige med å legge for stor vekt på hensynet til koherens i tilfeller hvor flere alternative tolkningsresultater kan være systemtro.

\section{DEN ULOVFESTEDE OVERLEVERINGSREGELEN}

Som nevnt i punkt 3 bidrar koherens til å fremme en indre systematikk på et fragmentert rettsområde som den dynamiske tingsretten. De klare systematiske linjene innenfor den dynamiske tingsretten bidrar til en stabilitet i rettsanvendelsen over tid. Den dynamiske tingsretten operere imidlertid ikke $i$ et juridisk og samfunnsmessig vakuum. Ønsket om å opprettholde en klar systematikk fordrer at systemet er i stand til å tilpasse seg nye verdier og

\footnotetext{
${ }^{41}$ Marthinussen: Tredjemannsproblemene s. 192.

${ }^{42}$ I samme retning, se Marthinussen: «Forusstranda» s. 72.
} 
behov som kan vokse frem med tiden. ${ }^{43}$ Den ulovfestede overleveringsregelen ved løsørekjøp kan kanskje illustrere hvordan hensynet til koherens potensielt kan stå i fare for å trumfe behovet for fornying av den dynamiske tingsretten. For å underbygge dette poenget er det nødvendig å redegjøre kort for det legislative grunnlaget for overleveringsregelen.

Norsk rett innehar ingen lovbestemmelse som avgjør hvordan løsørekjøper etablerer vern overfor selgers kreditorer. Den rådende oppfatningen i teorien synes i dag å være at overlevering i utgangspunktet er nødvendig for å etablere kreditorvern overfor selgers kreditorer, men at enkelte unntak kan tenkes. ${ }^{44}$

Overleveringsregelen har hovedsakelig vært grungitt i hensynet til notoritet. Et krav om notoritet i form av overlevering hevdes å være nødvendig for å motvirke faren for antedatering og problemer med å etterprøve påstander om kontante forskuddsbetalinger. ${ }^{45}$ Et annet argument som har vært anført i favør av et overleveringskrav, er at kreditorvernregelen ved løsørekjøp bør samsvar med håndpantregelen for å unngå kamuflerte håndpantsetteler. ${ }^{46}$

Slik jeg ser det kan ingen av de nevnte argumentene tillegges nevneverdig vekt ved etableringen av en ulovfestet overleveringsregel. Notoriteten som oppnås gjennom en overlevering av en løsøregjenstand, er svært liten. En overlevering sier ikke noe om når disposisjonen er foretatt, hvem som var parter i dispoisjonen og hva som var det nærmere innholdet i den. ${ }^{47}$

Faren for påstander om kontant forskuddsbetaling, er også lav i dag. Flere utsalgssteder har i løpet av den pågående pandemien nektet å ta imot kontant betaling, på tross av at norske

\footnotetext{
${ }^{43}$ Se Synne Sæther Mæhle: Grenser for rettsanvendelsesskjønn. Om rettslig legitimitet i et spenningsfelt mellom flertallsmakt og rettighetsvern, Oslo 2005 s. 129-130 som skriver om funksjonelle kontra substansielle legitimitetsmodeller. Hun mener et kjennetegn ved funksjonelle legitimitetsmodeller nettopp er at «det juridiske fagfellesskapet får et avgjørende ansvar for å sørge for adekvat og direkte respons fra retten på de stadige samfunnsmessige endringene».

${ }^{44}$ Falkanger/Falkanger: Tingsrett s. 766, Lilleholt: Allmenn formuerett s. 305, Høgetveit Berg: Beslagsretten s. 423-426, Mads Henry Andenæs: Konkurs, 3. utgave, Oslo 2009 s. 260-262, Hans Fredrik Marthinussen: «Rettsvern mot kreditorbeslag ved overdragelse og pantsettelse av panteretter», Jussens Venner nr. 2/2011 (volum 46) s. 87-130 på s. 92-93. DOI: https://doi.org/10.18261/issn1504-3126-2011-02-02 og Berte-Elen R Konow: «Den norske interesselæren og pragmatisme i norsk tingsrett» i Jan Kleineman (red.): Pragmatism v. principfasthet i nordisk förmögenhetsrätt, Stockholm 2019 s. 183-197 på s. 193. I litt mer reservert retning, se Borgar Høgetveit Berg: «Rettsvern for lausøyrekjøp - avtale eller overlevering (tradisjon)?», Jussens Venner nr. 1/1999 (volum 57) s. $\quad 1-30$ på s. 29. DOI: https://doi.org/10.18261/issn1504-3126-1999-01-01 og Marthinussen: Tredjemannsproblemene s. 217. Hilde Hauge konkluderer med at det ikke er grunnlag for å oppstille en hovedregel om overlevering, se Hauge: Løsøreerververs kreditorvern s. 193.

${ }^{45}$ Sjur Brækhus og Axel Hærem: Norsk tingsrett, Oslo 1964 s. 477-478 og s. 507-508. Ønsket om å motvirke kreditorsvik har også vært et viktig argument i favør tradisjonsprinsippet i svensk rett, se Staffan Myrdal: «Oklarheter med traditionsprincipen», Svensk Juristtidning s. 1074 på s. 1076.

${ }^{46}$ Hauge: Løsøreerververs kreditorvern s. 97, Lilleholt: Allmenn formuerett s. 305-306, Brækhus og Hærem: Norsk tingsrett s. 506-507, Andenæs: Konkurs s. 260-261, Høgetveit Berg: Beslagsretten s. 415-418 og Høgetveit Berg: «Rettsvern for lausøyrekjøp» s. 13-14.

${ }^{47}$ Brækhus: Omsetning og kreditt 3 og 4 s. 44.
} 
kontanter er tvunget betalingsmiddel. ${ }^{48}$ I en spørreundersøkelse Norges Bank gjennomført høsten 2020 fremgår det at bare fire prosent av betalinger nå skjer med kontanter. ${ }^{49}$ Over 90 prosent av betalingene skjer med betalingskort og mobiltelefoner. Mellom privatpersoner er betaling med kontanter nærmest ikke-eksisterende, og betaling via mobiltjenester som Vipps, MobilePay, Swish o.l. dominerer. Dessuten står netthandel i dag for en betydelig del av volumet ved løsøreomsetning. Ved netthandel stilles det som hovedregel krav om forskuddsbetaling fra forbrukere. Dette gjør at forskuddsbetaling snart vil kunne være den dominerende betalingsformen. ${ }^{50}$

Heller ikke faren for omgåelse av håndpantkravet er særlig stor. Bruken av håndpant er nærmest ikke-eksisterende i dag. Det finnes kun ett gjenværende pantelånkontor i Norge. Adgangen til å underpantsette løsøre ment for næringsvirksomhet har redusert behovet for håndpant. Faren for kamuflerte håndpantsettelser synes derfor ikke å være større enn at den bør tillegges minimalt med vekt, om overhode noen, ved etableringen av en ulovfestet rettsvernsregel ved løsørekjøp. For ordens skyld nevnes at proformakjøp som i realiteten er en håndpantsettelse, utvilsomt vil bli bedømt etter håndpantregelen i panteloven $\S 3-2 .{ }^{51}$

Den foreløpige gjennomgangen tilsier at det kan være behov for å underkaste overleveringsregelen en fornyet vurdering i lys av samfunnsendringene. Likevel er det eksempler i teorien på at overleveringsregelen legges til grunn som gjeldende rett uten nærmere drøftelse. Som eksempel kan det vises til Falkanger og Falkanger og Lilleholt sine fremstillinger av overleveringsregelen. Falkanger og Falkanger skriver for eksempel at det har «utkrystallisert seg den ulovfestede hovedregelen at løsøretingen må være fysisk overført til S (eller hans representant) for at disposisjonen skal stå seg i forhold til B», uten at det rettslige grunnlaget for regelen drøftes eller problematiseres i særlig grad. ${ }^{52}$ Kåre Lilleholt skriver følgende om overleveringskravet:

\footnotetext{
${ }^{48}$ Se sentralbankloven $\S 3-5$ første ledd og finansavtaleloven $\S 38$ tredje ledd.

${ }^{49} \mathrm{https}$ ://www.norges-bank.no/aktuelt/nyheter-og-hendelser/Foredrag-og-taler/2020/2020-11-05-bache/ (link sist sjekket 9. april 2021 klokken 12:44).

50 Alf Ross beskrev i sin tid forskuddsbetalinger som en «anomalitet», se Alf Ross: Ejendomsret og ejendomsovergang, København 1935 s. 162. Denne beskrivelsen er ikke treffende i dag.

${ }^{51}$ Lov 8. februar 1980 nr. 2 om pant. Se også Rt. 2008 s. 1170, avsnitt 54, Hilde Hauge: Løsøreerververs kreditorvern s. 95-96 og Sjur Brækhus: Omsetning og kreditt 2, 3. utgave ved Borgar Høgetveit Berg, Oslo 2005 s. 40 .

${ }^{52}$ Falkanger/Falkanger: Tingsrett s. 766. Se også Berte-Elen R Konow: «Den norske interesselæren og pragmatisme i norsk tingsrett» s. 193: «[J]eg [vil] for min del mene at det vel har festnet seg en oppfatning i norsk rett om at det gjelder et hovedprinsipp om overlevering/tradisjon».
} 
«Har vi ikkje gode grunnar for andre løysingar, kan omsynet til etablert oppfatning og innretting etter den oppfatninga i seg sjølv tilseie at vi held fast på eit utgangspunkt ein hovudregel - om at rettsvern krev fråtaking av innehaving $[\ldots] \gg .{ }^{53}$

Det er klart at verken Falkanger og Falkanger eller Lilleholt sikter til at overleveringsregelen har status som en rettsoppfatning hos private parter som har dannet grunnlag for en rettslig bindende sedvane. ${ }^{54}$ Flere har forsøkt å finne holdepunkter for en entydig praksis blant bostyrere og namsmenn rundt overleveringsregelen, uten å kunne fastslå en slik praksis. ${ }^{55}$ Det er, såvidt meg bekjent, heller ikke gjort forsøk på å avdekke om det foreligger noen entydig rettsoppfatningen eller praksis blant forskuddsbetalende løsørekjøpere, som også er en relevant aktør som må hensyntas ved drøftelse av løsørekjøpers kreditorvern. Slik jeg tolker Falkanger og Falkanger og Lilleholt synes de derfor å mene at en overleveringsregel bør gjelde av hensyn til koherens, selv om ingen av dem bruker begrepet koherens. Best kommer dette til utrykk når Lilleholt vektlegger behovet for å ha et utgangspunkt. Bak denne argumentasjonen synes det å ligge en forutsetning om at systemet blir mer oversiktlig og forutberegnelig om vi kan operere med en hovedregel om overlevering.

Til en viss grad kan jeg slutte meg til at dersom overleveringsregelen fjernes, vil det kunne oppstå noen systematiske utfordringer. De fleste fremstillingene av den dynamiske tingsretten har i etterkant av Brcekhus og Hoerems bok «Norsk tingsrett» fra 1964 tatt utgangspunkt i et overleveringskrav ved løsørekjøp, for deretter å drøfte hvorvidt det kan tenkes unntak i enkelte typetilfeller. ${ }^{56}$ Dersom denne systematikken brytes gjennom at overleveringsregelen ikke lenger skal anses å gjelde som en hovedregel, oppstår det unektelig enkelte systematiske utfordringer ved fremstillingene av løsørekjøpers kreditorvern. Likevel synes jeg innsigelsen om at overleveringsregelen bør opprettholdes av hensyn til den systematiske fremstillingen av faget er et forholdsvis svakt argument. Hensynet til koherens bør etter mitt skjønn ikke strekkes så langt at man opprettholder systemet utelukkende for systemets egen skyld.

\footnotetext{
${ }^{53}$ Lilleholt: Allmenn formuerett s. 305.

${ }^{54}$ Om sedvane som rettskildefaktor, se Eckhoff: Rettskildelcere s. 244 flg. og Skoghøy: Rett og rettsanvendelse s. $201 \mathrm{flg}$.

${ }^{55}$ Lilleholt: «Bruk av reelle omsyn i formueretten» s. 51, Høgetveit Berg: «Rettsvern for lausøyrekjøp» s. 8-9 og Andenæs: Konkurs s. 262.

${ }^{56}$ Se også Høgetveit Berg: «Rettsvern for lausøyrekjøp» s. 29: «Ein kan vel, utan å ta for hardt i, hevde at då Brækhus \& Hærem si bok 'Norsk tingsrett' kom i 1964, vart hovudregelen snudd - frå avtaleprinsipp til tradisjonsprinsipp. Samstundes oppstod behovet for vidtgåande unntak.»
} 
Enkelte har ment at den svake rettskildemessige forankringen til overleveringsregelen kan avhjelpes ved at det skal lite til for å oppstille unntak fra hovedregelen. ${ }^{57}$ Slik jeg ser det står en slik løsning i fare for å være inkoherent. Et grunnleggende trekk i den dynamiske tingsretten er at kreditorvernregler gjelder absolutt, uten at det er adgang til å oppstille skjønnsmessige unntak. En rettsvernsregel som åpner for vidtrekkende unntak, vil være en regel som ikke samsvarer med hvordan øvrige rettsvernsregler er bygd opp. Jeg synes særlig forbrukerunntaket, som av enkelte har vært fremhevet som et mulig unntak fra overleveringsregelen, er lite i samsvar med systematikken i den dynamiske tingsretten. ${ }^{58}$ Litt av poenget med kreditorvernregler er nettopp at de gjelder absolutt overfor alle erververe, uavhengig av om de er forbrukere eller profesjonelle. Et eventuelt forbrukerunntak gjør det mulig å hevde at forbrukerhensynet fra nå av kan anses som et relevant hensyn ved drøftelsen av rettighetskollisjoner, noe som etter mitt skjønn vil være et fremmedelement innenfor den dynamiske tingsretten. 59

Etter min oppfatning har en for sterk vektlegging av hensynet til koherens ført til at grunnlaget for overleveringsregelen i for liten grad har blitt underkastet fornyede vurderinger i norsk rett. ${ }^{60}$ Til sammenligning synes overleveringsregelen å stå mye svakere i svensk og dansk rett. ${ }^{61}$ Samfunnsutviklingen har løpt fra de begrunnelsene som tidligere talte i favør en overleveringsregel. Etter mitt skjønn er overleveringsregelen et eksempel på et uheldig utslag av hensynet til koherens, nemlig at koherens kan sperre for fornyede vurderinger av etablerte oppfatninger for å opprettholde innarbeidet systematikk. ${ }^{62}$

\footnotetext{
${ }^{57}$ Høgetveit Berg: «Rettsvern for lausøyrekjøp» s. 15-16 og s. 29, Høgetveit Berg: Beslagsretten s. 425 og Lilleholt: Allmenn formuerett s. 304-305.

${ }^{58}$ Lilleholt: Allmenn formuerett s. 307 og Høgetveit Berg: «Rettsvern for lausøyrekjøp» s. 24. I kritisk rettning, se Hans Fredrik Marthinussen: «Allmenn formuerett - Fleire rettar til same formuesgode» (bokanmeldelse), Lov og rett, nr. 4, 2013, s. 317-319 på s. 319. DOI: https://doi.org/10.18261/issn1504-3061-2013-04-06, Hauge: Løsøreerververs kreditorvern s. 187-188 og Høgetveit Berg: Beslagsretten s. 448-450.

${ }^{59}$ I samme retning, se Marthinussen: Tredjemannsproblemene s. 239.

${ }^{60}$ Hilde Hauges bok «Løsøreerververs kreditorvern» må sies å være et unntak i denne sammenheng.

${ }^{61}$ Selv om overlevering synes å være utgangspunktet også etter svensk rett, se Millqvist: Sakrättens grunder s. 144-145, har tradisjonsprinsippet fra og med 2002 ikke vært gjeldende ved forbrukerkjøp i svensk rett. I stedet er løsørekjøper vernet mot selgers kreditorer fra og med avtaleinngåelsen, se Konsumentköplag (1990:932) § 49. Våren 2015 ble det også lagt frem et forslag om å gå over til avtaleprinsippet i svensk rett, se SOU 2015:18 Lösöreköp och registerpant s. 9-11. Forslaget har foreløpig ikke blitt fulgt opp, se Torgny Håstad: «Spesialitetsprincipen, och pragmatiska undantag från denna» i Jan Kleineman (red.): Pragmatism v. principfasthet i nordiska förmögenhetsrätt, Stockholm 2019 s. 199-207 på s. 206-207. I dansk rett er ikke overlevering nødvendig for å oppnå rettsvern mot selgers kreditorer, se Mortensen: Indledning til tingsretten s. 228. I stedet synes det å være tilstrekkelig at en bindende individualisering i favør kjøper er foretatt, se Mortensen: Indledning til tingsretten s. 249 og Jens Paulsen: Insolvensret - Konkurs, København 2010 s. 325-326.

${ }^{62}$ Kinander har påpekt utfordringene som kan oppstå når man ikke underkaster tidligere inntatt perspektiver fornyede vurderinger, se Morten Kinander: «Sondringen mellom tinglige og obligatoriske rettigheter», Tidsskrift for rettsvitenskap $\mathrm{nr}$. 5/2003 (volum 116) s. 673-685 på s. 673-674. DOI: https://doi.org/10.18261/issn1504-3096-
} 


\section{SELVSTENDIG RETTSVERNSHEVD}

Når hensynet til koherens brukes som en beskrivelse av et tolkningsresultat, vil ofte hensikten være å fremheve at tolkningsresultatet er i tråd med systematikken innenfor den dynamiske tingsretten. Gjennom å bruke koherens på denne måten kan den som forsøker å systematisere rettsstoffet plassere et tolkningsresultat i en større sammenheng, hvor tolkningsresultatet ses $\mathrm{i}$ lys av rettsområdet som helhet. Det er likevel en viss fare for at ulike syn på grunnstrukturene innenfor den dynamiske tingsretten kan føre til ulike syn på hva som utgjør koherent argumentasjon. I verste fall kan dette føre til at rommet for rettslig argumentasjon blir mindre som en konsekvens. Diskusjonene som har vært ført i teorien om selvstendig rettsvernshevd kan kanskje illustrere dette poenget.

Kort oppsummert brukes selvstendig rettsvernshevd som en betegnelse på at «man har en gyldig stiftet rett, slik at retten ikke hevdes, men man likevel ved å ha hatt eiendom som sin i hevdstid, får etablert rettsvern». ${ }^{63}$ Selvstendig rettsvernshevd er ikke hjemlet i lov, og må derfor eventuelt oppstilles som en ulovfestet regel. ${ }^{64}$ I Forusstranda-dommen konkluderte Høyesterett med at en eiendomskjøper som bevisst unnlot å tinglyse sitt eiendomserverv for å spare dokumentavgift, ikke var beskyttet mot selgers kreditorer gjennom den ulovfestede regelen om selvstendig rettsvernshevd. ${ }^{65}$

I etterkant av Forusstranda-dommen har det vært drøftet om, og eventuelt i hvilket omfang, det fortsatt eksisterer en ulovfestet regel om selvstendig rettsvernshevd. Om dette finnes det ulike oppfatninger i teorien. ${ }^{66}$ En mulig tolkning er at selvstendig rettsvernshevd fortsatt kan være aktuelt i noen snevre unntakstilfeller, hvor de hensynene som ellers ligger til grunn for ekstinksjonsreglene taler for å beskytte suksessor, herunder hensynet til å motvirke kreditorsvik, notoritet, publisitet, legitimasjon og god tro. Jeg har selv gått inn for en slik

2003-05-03: «Men det er allikevel en parallell her til rettsvitenskapen: Vi snakker om perspektiver, perspektiver man inntar, som lett fungerer som en virkelighetsforståelse, ja, som fungerer som betingelser for å komme fram til en noenlunde koherent og forståelig oppfatning av den juridiske verden. Men som alltid når det er snakk om perspektiver av en slik styrke at de fungerer som forståelsesbetingelser, står man i fare for å glemme at de en gang var et resultat av argumentative svar på presserende spørsmål. Og når spørsmålene endrer seg, må man også endre svarene.»

${ }^{63}$ HR-2017-33-A, avsnitt 56.

${ }^{64}$ For en nærmere gjennomgang av det rettslige grunnlag for selvstendig rettsvernshevd, se Sverre Magnus Bergslid Salvesen: «Selvstendig rettsvernshevd i lys av HR-2017-33-A», Jussens Venner nr. 4/2018 (Volum 53) s. 205-226 på s. 205-212. DOI: https://doi.org/10.18261/issn. 1504-3126-2018-04-01.

${ }^{65}$ Sammenlign det rettslige spørsmålet som oppstilles i HR-2017-33-A, avsnitt 58 med konklusjonen i avsnitt 64.

${ }^{66}$ Se Marthinussen: «Forusstranda» s. 67-97 på s. 89-94, Salvesen: «Selvstendig rettsvernshevd i lys av HR-201733-A» s. 205-226, Gunnar Eriksen: «Et kritisk blikk på reglene om rettsvernshevd» i Trude Haugli m.fl. (red.): Dette brenner jeg for. Festskrift til Hege Brckhus 70 år, Bergen 2020 s. 85-97 og Høgetveit Berg: Beslagsretten s. 353-364. 
tolkning av selvstendig rettsvernshevd.$^{67}$ En annen mulig tolkning er at det ikke lenger er rom for en regel om selvstendig rettsvernshevd. Dette kan begrunnes med at selvstendig rettsvernshevd potensielt bryter med det systemet som rettsvernsreglene er bygd opp etter. Et slikt tolkningsresultat kan forutsette en systemforståelse hvor det ikke er rom for ulovfestede regler som åpner for skjønnsmessige unntak fra de positivrettslige kreditorvernreglene. Hans Fredrik Marthinussen synes blant annet å gå inn for en slik tolkning av selvstendig rettsvernshevd. ${ }^{68}$

Diskusjonen rundt selvstendig rettsvernshevd kan kanskje avdekke et metodisk poeng: Ulike forståelser av grunnstrukturen til et rettsområde, kan få betydning for hva som kan anses som koherent argumentasjon. ${ }^{69}$ Der jeg mener rettsvernssystemet ikke nødvendigvis sperrer for en ulovfestet regel om selvstendig rettsvernshevd, synes Marthinussen å mene at kreditorvernregler må gjelde absolutt, og at det derfor ikke er grunnlag for å drøfte selvstendig rettsvernshevd på bakgrunn av de hensynene som potensielt kan tale for en slik regel. Både min og Marthinussens systemforståelse av rettsvernsreglene kan hypotetisk sett være forsvarlig. Hvilken tolkning som skal anses for å være koherent, vil til en viss grad være avhengig av hvilken normativ plattform som man mener rettsvernsreglene hviler på. Mer spesifikt er spørsmålet hvor absolutt rettsvernsreglene må være. Legger man til grunn at det overhodet ikke er adgang til å etablere rettsvern på andre måter enn dem som er lovfestet, vil en regel om selvstendig rettsvernshevd være inkoherent. Selvstendig rettsvernshevd trenger imidlertid ikke å være inkoherent i den grad man legger til grunn at rettsvernsreglene ikke nødvendigvis må være absolutt i ethvert tilfelle.

Man kan også se diskusjonen om selvstendig rettsvernshevd som et utslag av to ulike syn på hvordan man kan gå frem i rettsanvendelsen. Den første måten man kan gå frem på er at man tar utgangspunkt i grunntrekk ved det rettsområdet man befinner seg på, for deretter å søke og tilpasse en konkret tolkning til rettsområdets grunntrekk. Dette kan kalles en «ovenfra og ned»tilnærming. Den andre måten man kan gå frem på beskrives av Arnt Skjefstad. Skjefstad går inn for at man skal «identifisere interessemotsetningene og hva som er problemet $\mathrm{i}$ denne saken, og deretter se seg om etter rettsmateriale som kan gi bidrag til løsningen av dette rettsspørsmålet

\footnotetext{
${ }^{67}$ Salvesen: «Selvstendig rettsvernshevd i lys av HR-2017-33-A» s. 205-226.

${ }^{68}$ Marthinussen: Tredjemannsproblemene s. 91-92. Se også Marthinussen: «Forusstranda» s. 89-94.

${ }^{69}$ Ulike syn på grunnstrukturen kan kanskje sammenlignes med det Synne Sæther Mæhle omtaler som «de grunnleggende verdimessige spenningene i det rettsfeltet som argumentasjonen dreier seg om», se «Gjelder det andre regler for rettslige argumentasjon i rettsdogmatikken enn for domstolene?», Jussens Venner nr. 5-6/2004 (volum 39) s. 329-342 på s. 335. DOI: https://doi.org/10.18261/issn1504-3126-2004-05-06-04.
} 
mellom disse partene med dette faktumet». ${ }^{70}$ Dette kan omtales som en «nedenfra og opp»»tilnærming til rettsanvendelsen.

I den dynamiske tingsretten er det større tradisjon for å innta en «ovenfra og ned»-tilnærming til rettsanvendelsen enn på mange andre rettsområder. Det er nødvendig med klare regler som fremmer forutberegnelighet for kredittaktørene i markedet, noe som forutsetter en «ovenfra og ned»-tilnærming. En konkurs vil aldri kunne sørge for at alle kreditorene får full dekning for sitt krav, en realitet som fordrer brutale resultater. ${ }^{71}$ På et område som erstatningsretten, som blant andre Skjefstad skriver innenfor, er det nok i større grad tradisjon for å avveie partsinteressene i den konkrete saken i et forsøk på å gjennopprette balansen mellom skadevolder og skadelidte. Jeg tror likevel at man i for stor grad har hatt en «ovenfra og ned»tilnærming ved tolkningen av kreditorvernregler, hvor de grunnleggende verdiene som man tar med seg inn i tolkningen av kreditorvernregler utelukkende tilgodeser kreditorene, og ikke den enkelte suksessoren som ofte kan fremstå svært verneverdig i møte med skyldnerens alminnelige kreditorer. ${ }^{72}$ Den normative plattformen som den dynamiske tingsretten hviler på, kan derfor tidvis virke så tung og fastgrodd at systemet selv står $\mathrm{i}$ fare for å svekke argumentasjonsrommet.

\section{OPPSUMMERING}

For å oppsummere er det ikke tvilsomt at det er behov for å ta hensyn til koherens innenfor den dynamiske tingsretten. Hensynet til koherens sørger for større forutberegnelighet, effektiv konkursavvikling og færre rettslige prosesser. ${ }^{73}$ Dette er særlig viktig på et rettsområde som den dynamiske tingsretten, hvor klare retningslinjer og forutberegnelighet er essensielt. Behovet for koherenstenkning er stort når man i norsk rett har en funksjonell tilnærming fremfor en substansiell tilnærming til eiendomsretten. I et rettsystem som inntar en substansiell tilnærming til retten, vil tidspunktet for eiendomsrettens overgang kunne være et formelt utgangspunkt for diskusjoner om tredjepersons rettsstilling. Ved en funksjonell tilnærming til eiendomsretten mangler et slikt utgangspunkt. Gjennom koherenstenkning slipper imidlertid

\footnotetext{
${ }^{70}$ Sitatet er hentet fra Arnt E. Skjeftad: «Metodiske utfordringer i erstatningsretten - noen grunntrekk og refleksjoner», Tidsskrift for erstatningsrett, forsikringsrett og trygderett, nr. 4/2018 (Volum 15) s. 220-260 på s. 254. DOI: https://doi.org/10.18261/issn.2464-3378-2018-04-02.

${ }^{71}$ I samme retning, Kåre Lilleholt: «Hans Fredrik Marthinussen: Tredjemannsproblemene. Om formuerettslige argumentasjonsmønstre» (bokanmeldelse), Tidsskrift for rettsvitenskap nr 2-3/2017 (Volum 130) s. 301-302 på s. 302. DOI: https://doi.org/10.18261/issn.1504-3096-2017-02-03-08.

${ }^{72}$ Ulf Göranson synes å være inne på lignende tankegods, se Ulf Göranson: Traditionsprincipen, Uppsala 1985 s. $21-22$.

${ }^{73}$ Tørum: «Konsekvens i formueretten» s. 333.
} 
rettsanvenderen å foreta vanskelige avveininger i enhver sak på et område hvor selv små justeringer kan få forholdsvis store konsekvenser for markedet. Det er også lettere å forklare og forstå et tolkningsresultat som inngår i et klart system, enn et tolkningsresultat som er bygd opp fra grunnen av i hver enkelt sak. Man skal derfor ikke underspille den pedagogiske fordelen som oppnås ved å fremstille et fragmentert rettsområde på en systematisk og helhetig måte. ${ }^{74}$

Hensynet til koherens kan imidlertid også føre med seg noen uheldige virkninger som jeg har forsøkt å belyse i denne artikkelen. Når koherens anvendes som et reelt hensyn i den konkrete rettsanvendelsen, vil ofte flere ulike tolkningsalternativer kunne hevdes å være systemtro. ${ }^{75}$ Hvilken tolkning som skal anses for å være mest koherent, vil være avhengig av hvilke regler, hensyn eller prinsipper som tolkningsobjektet vurderes i lys av. Hensynet til koherens kan i slike tilfeller bidra med lite, og kan i verste fall bli brukt som et argument for at rettsanvenderne skal slippe å foreta den hensynsavveiningen som en regel legger opp til.

Hensynet til koherens kan potensielt også åpne for systemslutninger hvor rettslige avgjørelser tilpasses grunnverdier i den dynamiske tingsretten, fremfor at det foretas en avveining av de relevante rettslige kildene. Rommet for rettsuvikling kan i så fall bli svært lite. Nyere krav fra samfunnet kan stå i fare for ikke å bli hensyntatt i rettsanvendelsen. En eventuell kursendring må i så fall skje fra lovgivers side. Historisk sett har lovgiveraktiviteten innenfor den dynamiske tingsretten vært forholdsvis lav, noe som stiller krav til at rettsutvikling til en viss grad $b ø r$ skje gjennom et samspill mellom teorien og rettspraksis. Rettsutvikling kan imidlertid være vanskelig å oppnå når den normative plattformen til den dynamiske tingsretten er såpass fastlåst at det uten videre anses uproblematisk å fatte avgjørelser som utelukkende er begrunnet $\mathrm{i}$ behovet for en klar systematikk. ${ }^{76}$

Et nærliggende faremoment ved å betone hensynet til koherens for mye, er også at normative oppfatninger om innholdet i den dynamiske tingsrettens struktur kan virke sensurerende for hvilke argumenter som skal regnes for å være koherente eller inkoherente. I verste fall kan den enkelte rettsanvenderens normative oppfatninger om innholdet $\mathrm{i}$ fagets grunnstrukturer $\mathrm{i}$ seg selv virke normerende. Systemslutninger basert på kamuflerte normative oppfatninger leder

\footnotetext{
74 Tørum: «Konsekvens i formueretten» s. 338.

${ }^{75}$ Se i denne retning Lilleholt: «Tredjemannsproblemene» (bokanmeldelse), s. 302: «Vi kan oppleva at resonnement etter ulike tankeliner - som alle kan vera fullgodt baserte på omsyn og samanheng - fører til ulike løysingar. Slik er det både i den allmenne formueretten og på andre rettsområde. Dissensar i dei høgste domstolane er illustrerande: Både fleirtal og mindretal har rimeleg nok - og iallfall oftast - ei solid grunngjeving for sitt standpunkt, og når dei kjem til ulike resultat, kan ikkje dette alltid forklårast med skilnad i metodiske grunnsyn.» ${ }^{76}$ Se Rt. 1997 s. 1050 på s. $1054-1055$ og Rt. 1998 s. 268 på s. 275.
} 
tanken mot kritikken som i sin tid ble ført mot det «metafysiske» eiendomsrettsbegrepet, og som den funksjonelle tilnærmingen til eiendomsretten nettopp skulle være en medisin mot.

En økt bevissthet rundt innholdet og grensene for koherens som hensyn innenfor den dynamiske tingsretten, er en diskusjon jeg ønsker velkommen. Kanskje kan en diskusjon rundt koherenshensynets innhold øke den metodiske bevisstheten innenfor faget. 